\title{
Theoretical free energies of electron transfer, electrochemical properties, electron transfer kinetic and quantitative structural relationships studies of alkynyldihydrofullerene in [X-UT-Y] $\left[\mathrm{R}-\mathrm{C}_{60}{ }^{-} \mathrm{M}^{+}\right]$supramolecular complexes
}

\author{
Avat Arman Taherpour a,*, Masomeh Tayebi-Suraki ${ }^{\mathrm{b}}$ and Nosratollah Mahdizadeha \\ a Department of Organic Chemistry, Faculty of Chemistry, Razi University, P.O. Box: 67149-67346, Kermanshah, Iran \\ b Chemistry Department, Faculty of Science, Islamic Azad University, 38135-567, Arak, Iran \\ ${ }^{*}$ Corresponding author at: Department of Organic Chemistry, Faculty of Chemistry, Razi University, P.O. Box: 67149-67346, Kermanshah, Iran. \\ Tel.: +98.831.4274559; fax: +98.831.4274559. E-mail address: avatarman.taherpour@gmail.com (A.A. Taherpour).
}

\section{ARTICLE INFORMATION}

Received: 13 April 2012

Received in revised form: 10 July 2012

Accepted: 11 July 2012

Online: 30 September 2012

\section{KEYWORDS}

Fullerenes

Marcus theory

Non-IPR Carbon Cage

Rehm-Weller equation

Unsaturated thiocrown ethers

Alkynyldihydrofullerene derivatives

\section{ABSTRACT}

The isolated pentagon rule (IPR) states that all pentagonal carbon rings are isolated in the most stable fullerenes. Fullerenes (buckministerfullerene) are a class of spherical carbon allotrope group with unique properties. Electron transfer between fullerene $\mathrm{C}_{60}$ derivatives such as alkynyldihydrofullerene (1-alkynyl- $\mathrm{C}_{60}$ carbanion) and other molecules are thought to involve the transfer of electrons between molecules surrounding the fullerene cage. One class of electron-transfer molecules has introduced as $[\mathrm{X}-\mathrm{UT}-\mathrm{Y}]\left[\mathrm{R}-\mathrm{C}_{60} \mathrm{O}^{\mathrm{M}} \mathrm{M}\right](\mathrm{R}=$ tert-Bu- \& $\mathrm{H}-\mathrm{C} \equiv \mathrm{C}-$; $\mathrm{M}=\mathrm{Li} \& \mathrm{~K})$. The supramolecular complexes [X-UT-Y] (1-9) and $\left[\mathrm{R}-\mathrm{C}_{60} \mathrm{M}^{\mathrm{H}}\right](\mathrm{R}=$ tert-Bu- \& $\mathrm{H}-$ $\mathrm{C} \equiv \mathrm{C}$-; $\mathrm{M}=\mathrm{Li} \& \mathrm{~K}$ ) are shown to possess a previously unreported host-guest interaction for electron transfer processes. The unsaturated, thiocrown ethers (1-9, with cis-geometry) (described as [X-UT-Y], where $\mathrm{X}$ and $\mathrm{Y}$ indicate the numbers of carbon and sulfur atoms, respectively) are a group of crown ethers that display interesting physiochemical properties in light of their conformational restriction compared to a corresponding saturated system, as well as the sizes of their cavities. Topological indices have been successfully used to construct mathematical methods that relate the structural data to the various chemical and physical properties. To establish a good relationship between the structures of 1-9 with derivatives of alkynyldihydrofullerene (1-alkynyl- $\mathrm{C}_{60}$ carbanion) as $\left[\mathrm{R}-\mathrm{C}_{60} \mathrm{O}^{\mathrm{M}}+\mathrm{C}=\right.$ tert-Bu- \& $\mathrm{H}-\mathrm{C} \equiv \mathrm{C}-; \mathrm{M}=\mathrm{Li}$ $\& \mathrm{~K})$ in DMSO and THF solvents $\mathbf{1 2 - 3 8}$, an index $\left(\mu_{c s}\right)$ is utilized. This index is the ratio of the sum of the number of carbon atoms $\left(n_{c}\right)$ and the number of sulfur atoms $\left(n_{s}\right)$ with the product of these two numbers for 1-9. In this study, were investigated the relationships between this index and the first to third free energies of electron transfer $\left(\Delta G_{e t(n)} ; \mathrm{n}=1-3\right.$, which is given by the Rehm-Weller equation) between 1-9 and $\left[\mathrm{R}-\mathrm{C}_{60} \mathrm{M}^{-} \mathrm{M}^{+}\right](\mathrm{R}=$ tert-Bu- \& $\mathrm{H}-\mathrm{C} \equiv \mathrm{C}-; \mathrm{M}=\mathrm{Li} \& \mathrm{~K})$ as $[\mathrm{X}-\mathrm{UT}-\mathrm{Y}]\left[\mathrm{R}-\mathrm{C}_{60}{ }^{-} \mathrm{M}^{+}\right](\mathrm{R}=$ tert-Bu- \& $\mathrm{H}-\mathrm{C} \equiv \mathrm{C}-; \mathrm{M}=\mathrm{Li} \& \mathrm{~K})$ supramolecular complexes in DMSO and THF solvents. The first to third free energies of electron transfer and the kinetic rate constants of the electron transfers, $\Delta G^{\#} e t(n)$ and $k_{e t}(\mathrm{n}=1-3)$, respectively, were also calculated for [X-UT$\mathrm{Y}]\left[\mathrm{R}-\mathrm{C}_{60} \mathrm{M}^{\mathrm{N}}\right](\mathrm{R}=$ tert-Bu- \& $\mathrm{H}-\mathrm{C} \equiv \mathrm{C}-; \mathrm{M}=\mathrm{Li} \& \mathrm{~K})$ in DMSO and THF, in accordance with the Marcus theory.

\section{Introduction}

In 1985 fullerenes were demonstrated as one of the uniquely stable molecular allotropic formsof carbon [1,2]. Fullerenes are more reactive than planar aromatics, acts as an important driving force for the additional reactions. This property returns to the reduction of the strain energies, which results from pyramidalization in the $s p^{2}$-carbon network $[3,4]$. One of the simplest compounds in the huge family of fullerenes is $\mathrm{C}_{60}$ [3]. Since 1985, metal-containing endohedral fullerenes (EMFs) have attracted special attention as a new class of technologically relevant material due to their combined fullerene-like and metallic properties. In most EMFs, introduction of metal atoms into carbon cages leads to an increase in the electron affinity relative to the corresponding empty-cages $[2,5,6]$. Endohedral metallofullerenes (EMFs) have shown very interesting applications in optoelectronic devices since varying the encapsulated metal cluster can change the optical and electronic properties, without changing the structural features of the outer carbon shell. Enhancement of third-order nonlinear optical susceptibility observed in EMFs further establishes them as potential candidates for nonlinear optical devices $[2,3]$. In early studies, La@ $\mathrm{C}_{60}$ was examined by Kroto et al., although it was never isolated in solid form [1,2]. A variety of endohedral metallofullerenes have been reported, but their investigations have been limited because they were typically formed in extremely low yields [2]. Various theoretical techniques have been employed to study the electronic, structural and vibrational properties of fullerenes and their derivatives [2]. These studies have revealed the structure of the fullerene cages, the electronic states of metal atoms and fullerene cages, and how the electronic properties and chemical reactivity of empty fullerene cages change upon endohedral metal doping [2]. EMFs of carbon cage size in the range between $\mathrm{C}_{66}$ and $\mathrm{C}_{84}$ were shown to be stable structures although the corresponding empty fullerenes are either not stable or have been isolated only in minor quantities in the fullerene soot [2]. 
Among fullerenes, many of them do not follow the IPR rule. There are several ways in which the IPR can be violated; one way is to generate fused-pentagons in which the pentagons are adjacent to one another [2]. All pentagonal carbon rings are isolated in the most stable fullerenes, in accordance with the isolated pentagon rule (IPR). The IPR has proved valuable in understanding the stability of cage structures of fullerenes and metallofullerenes [3]. The most abundant fullerenes, $\mathrm{C}_{60}$ and $\mathrm{C}_{70}$ and all pure carbon fullerenes larger than $\mathrm{C}_{70}$ follow the IPR [8-11]. Non-IPR fullerenes, which contain adjacent pentagons (APs), have been stabilized experimentally in cases where it is topologically impossible to fully isolate all the pentagons, in accordance with Euler's theorem [8]. Alcami et al. have shown that, apart from strain, the most important physical property that governs the relative stabilities of fullerenes is the charge distribution within the cage [8]. This charge distribution is controlled by the number and location of APs and pyrene motifs. Alcami et al. have also shown that, when these motifs are uniformly distributed and well-separated from one other, stabilization of non-IPR endohedral and exohedral derivatives, as well as pure carbon fullerene anions and cations, becomes the rule, rather than the exception. This suggests that non-IPR derivatives might even be more common than IPR derivatives [8].

Fullerenes violating the IPR are only obtained in derivatized form, since the [5,5]-bond carbons readily react to release bond strain. However, non-IPR fullerenes still have unsaturated $s p^{2}$ carbons at the [5,5] bond junctions, which allow their chemical properties to be probed [8-11]. It is concluded that although the fused-pentagon sites are very reactive toward a carbene, the carbons forming the $[5,5]$ junctions are less reactive than the adjacent ones; this confirms that these carbons interact strongly with the encaged metals and are stabilized by them [11].

For $\mathrm{C}_{60}$ and $\mathrm{C}_{72}$, only one IPR structure is consistent with their symmetry. Theoretical studies on $\mathrm{C}_{60}$ and $\mathrm{C}_{72}$ have shown that the non-IPR-satisfying structures are more stable than the IPR-satisfying structures [8-15]. It is believed that the fusedpentagon pairs in non-IPR EMFs are stabilized by electron transfer from the encapsulated metals to the carbon cage [16]. Actually, both experimental results and theoretical calculations have indicated that the encaged metals are associated with the fused-pentagon pairs in non-IPR EMFs, but more direct experimental proof is still lacking [16,17-24]. Furthermore, unlike the exohedrally derivatized non-IPR fullerenes, non-IPR EMFs still bear unsaturated $s p^{2}$ carbons at the $[5,5]$ bond junctions, and thus, it is of special interest to elucidate the properties and chemical reactivities of the fused pentagons. However, little is known about the properties of non-IPR fullerenes and non-IPR EMFs [16]. The non-IPR fullerenes are always attractive not only because of their unique structures, which contain fused pentagons, but also because of their unusual properties resulting from the high curvatures around the adjacent pentagons $[16,25,26]$.

It is a well known fact that fullerene $\mathrm{C}_{60}$ is a highly electronegative molecule. So, it readily undergoes nucleophilic reactions $[27,28]$. After the interesting work by Wudl et al. [29], Hirsch and co-workers [30] studied the reaction with various organolithium and Grignard reagents, which gave monoalkyldihydrofullerenes with well-defined structures after protonation. Fagan et al. [31] reported the synthesis and properties of tert-butyl- $\mathrm{C}_{60}$ anion by means of nuclcophilic addition of tert-butyllithium to $\mathrm{C}_{60}$ [27]. The fullerenyl proton in the tert-butyl derivative was shown to be highly acidic with the pKa value of 5.7 [31]. Since an ethynyl group has electronwithdrawing inductive effects [32] as compared with alkyl groups, it was expected that $\mathrm{C}_{60}$ bearing an ethynyl group, $\mathrm{R}$ $\mathrm{C} \equiv \mathrm{C}-\mathrm{C}_{60}-\mathrm{H}$, would give even more stable carbanion than tert$\mathrm{Bu}^{-} \mathrm{C}_{60^{-}}[27,33]$. However, these derivatives were not quite suitable for the study of their anions, since the phenylethynyl derivative was only soluble in common organic solvents and the trimethylsilylethynyl derivative was rather unstable under basic conditions. In 1996, Komatsu et al. prepared a 1-octynyl derivative, $\mathrm{Hex}-\mathrm{C} \equiv \mathrm{C}-\mathrm{C}_{60}-\mathrm{H}(\mathbf{1})$, which was expected to be more soluble and chemically stable. The synthesis, properties, and reactions of 1-octynyl- $\mathrm{C}_{60}$ anion (2-) bearing $60 \pi$-electrons on the $\mathrm{C}_{60}$ core, which was readily generated from $1\left(\mathrm{R}-\mathrm{C}_{60}-\mathrm{M}^{+}\right.$; $\mathrm{R}=$ tert $-\mathrm{Bu}-\& \mathrm{H}-\mathrm{C} \equiv \mathrm{C}-)$ were reported by Komatsu et al. $[27,33]$.

The unsaturated, cis-thiocrown ethers (1-9), comprise a group of compounds with interesting physiochemical properties, in light of their conformational restrictions compared to corresponding saturated systems and the sizes of their cavities. The presence of sulfur atoms gives rise to the unique properties of thiocrown ethers. The cis-unsaturated thiocrown ethers (described as [X-UT-Y], where $\mathrm{X}$ and $\mathrm{Y}$ indicate the numbers of carbon and sulfur atoms, respectively), 1-9, were synthesized and their structures were confirmed [3443]. 1,4-Dithiin is the smallest member of compounds 1-9 that has been widely studied [44-54]. In 2001, the structures of [XUT-Y] $(X=6,9,12,15,18,21,24$ and 27 and $Y=2$-9) $\mathbf{1 - 9}$ were reported by Tsuchiya et al. [34] In that report, the ${ }^{1} \mathrm{H}$ and ${ }^{13} \mathrm{C}$ NMR spectra, $x$-ray crystallographic data, ORTEP drawings, cavity size, and UV spectra of [X-UT-Y] 1-9 were carefully considered [34]. The $\mathrm{x}$-ray crystal structures and ORTEP drawings for some members of $\mathbf{1 - 9}$ [X-UT-Y], namely $X=15,18$, 21,24 and 27 and $Y=5-9$, show the presence of cavities and a nearly coplanar arrangement of sulfur atoms [34]. The average radii of the cavities for $\mathbf{4 - 8}$ were found to be 1.76, 2.34, 3.48, 4.43 and $5.36 \AA$, respectively [34]. The previously reported ${ }^{13} \mathrm{C}$ and ${ }^{1} \mathrm{H}$-NMR spectra in $\mathrm{CDCl}_{3}$ showed that compound $\mathbf{4}$ has the highest chemical shifts. The electron densities of the $\mathrm{C}=\mathrm{C}$ bonds increase with the increasing ring size from $\mathbf{4}$ to $\mathbf{9}$ and decrease from 4 to 1 with the decreasing ring size [34,35]. In 2006, the oxidation potential $\left({ }^{o x} E_{1}\right)$, cyclic voltammograms $\left(\mathrm{Fc} / \mathrm{Fc}^{+}\right)$, and free energies of electron transfer $\left(\Delta G_{e t}\right)$ of supramolecular complexes of $[\mathrm{X}-\mathrm{UT}-\mathrm{Y}]\left[\mathrm{C}_{60}\right]$ with cis-unsaturated thiocrown ethers, 1-9, were considered by Tsuchiya et al. [35]. The EMFs and their complexes with the thiocrown ethers have shown interesting properties for applications and basic research studies.

The wide variety of useful applications of graph theory shows that this branch of discrete mathematics can benefit various fields of sciences. Graph theory has been found to be an effective tool in QSAR and QSPR [55-60]. A graph is a topological concept rather than a geometrical concept, and hence Euclidean metric lengths, angles and three-dimensional spatial configurations have no meaning. Numerous studies have related these fields using topological indices (TI) [60]. Numerous applications have shown that one can utilize the topological index as a very useful tool for molecular structural studies, which can be used to describe and predict reactivity and structural properties, in addition to biological and toxicological characters of compounds. One group of TI was founded by Randic, who introduced the molecular branching index [61]. In 1975, Randic proposed a topological index that has become one of the most widely used in both QSAR and QSPR studies. However, the most important contribution of this stage is probably the development of a great number of applications of TIs in several fields of chemistry. The TIs are based on Randic's original idea of molecular branching, but have been extended to account for contributions coming from path clusters, clusters, and chains of different lengths [62-69]. A burst in the research into TIs began during the 1990s, and is marked by an increase in the number of studies and applications of TIs in chemistry $[70,78]$. Among the successful TIs in these applications, it is worth noting the molecular connectivity indices [70,71] (including the Randic index [61]), the Randic index [61, 65-69,79-83], the Kier indices [73,74], the elecro-topological state indices [75], the Balaban index [75], and the Wiener index [72]. Trinajstic and coworkers have reported that 39 topological indices are presently available in the literature $[78,84,85]$. 
Table 1. The reduction potentials ${ }^{r e d} E_{n}\left(\mathrm{n}=1-3\right.$ in Volt) of $\mathrm{R}-\mathrm{C}_{60} 0^{-} \mathrm{M}+$; $\mathrm{R}=$ tert $-\mathrm{Bu}-\&$ Hex-C $\equiv \mathrm{C}-, \mathrm{M}=\mathrm{Li} \& \mathrm{~K} .{ }^{a}$

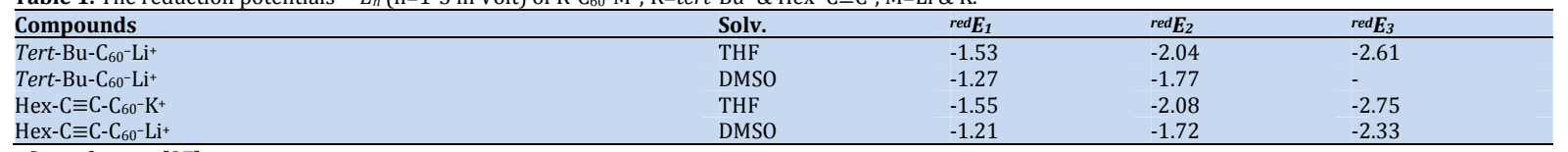

${ }^{a}$ See reference [27].

Estrada has performed important studies of generalized TIs with several topological indices in the graph invariant [79]. In 1993 and 1997, the Wiener and Harary indices were applied to studies of fullerenes [85-87]. The use of effective mathematical methods in making strong correlations between chemical properties and the indices has been reported [80-90], which is an important area of development. The ratio of the sum of the number of carbon atoms $\left(n_{c}\right)$ to the number of sulfur atoms $\left(n_{s}\right)$ to the product of these two numbers $\left(\mu_{c s}\right)$ was a useful numerical and structural value in the studies reported here on the unsaturated thiocrown ethers 1-9 [86-90].

Quantitative structural relationships studies of the $\mu_{c s}$ index with respect to the oxidation potentials $\left({ }^{o x} E_{1}\right)$ of thiocrown ethers (1-9), as well as the free energy of electron transfer $\left(\Delta G_{e t}\right)$ between 1-9 with fullerenes and some of the EMFs were previously reported [16,86-91].

Here, the relationships between this index and oxidation potential $\left({ }^{\circ x} E_{1}\right)$ of $\mathbf{1 - 9}$, as well as the first and second free energies of electron transfer $\left(\Delta G_{e t(n)}\right.$, for $n=1,2$, which is given by the Rehm-Weller equation) between 1-9 and $\left[\mathrm{R}-\mathrm{C}_{60} \mathrm{M}^{+}\right]$ $(\mathrm{R}=$ tert-Bu- \& $\mathrm{H}-\mathrm{C} \equiv \mathrm{C}-; \mathrm{M}=\mathrm{Li} \& \mathrm{~K})$ and their supramolecular complexes derivatives as [X-UT-Y] $\left[\mathrm{R}-\mathrm{C}_{60} \mathrm{M}^{+}\right](\mathrm{R}=$ tert-Bu- \& $\mathrm{H}-$ $\mathrm{C} \equiv \mathrm{C}-; \mathrm{M}=\mathrm{Li} \& \mathrm{~K})$ in DMSO and THF solvents, are presented and investigated. The first to third free energies of electron transfer and kinetic rate constants of the electron transfers, $\Delta G^{\#} e t(n)$ and $k_{e t}(\mathrm{n}=1-3)$, respectively, were also calculated in this study for [X-UT-Y][R-C $\left.60^{-} \mathrm{M}^{+}\right](\mathrm{R}=$ tert-Bu- \& $\mathrm{H}-\mathrm{C} \equiv \mathrm{C}-; \mathrm{M}=\mathrm{Li} \& \mathrm{~K})$ in DMSO and THF solvents and in accordance with the Marcus theory [16,88-93], Figure 1.

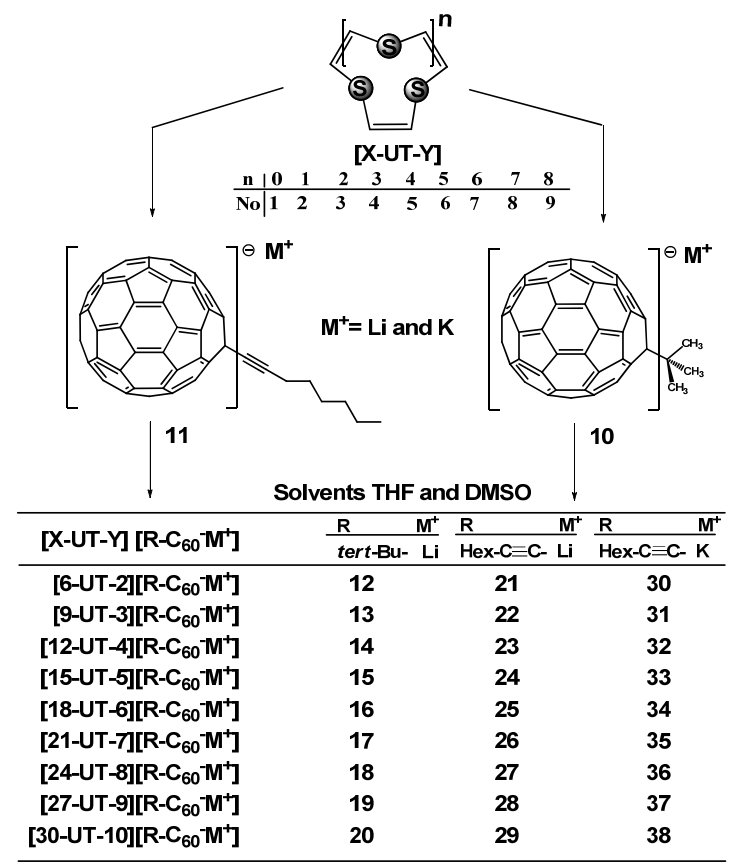

Figure 1. The structures of unsaturated thiocrown ethers 1-9 with [R- $\mathrm{C}_{60^{-}}$ $\left.\mathrm{M}^{+}\right](\mathrm{R}=$ tert $-\mathrm{Bu}-\& \mathrm{H}-\mathrm{C} \equiv \mathrm{C}-; \mathrm{M}=\mathrm{Li} \& \mathrm{~K}) \mathbf{1 0}$ and $\mathbf{1 1}$, to produce supramolecular complexes [X-UT-Y] $\left[\mathrm{R}-\mathrm{C}_{60}{ }^{-} \mathrm{M}^{+}\right](\mathrm{R}=$ tert-Bu- \& Hex-C $\equiv \mathrm{C}-; \mathrm{M}=\mathrm{Li} \& \mathrm{~K}) \mathbf{1 2 - 3 8}$.

\section{Graphing and mathematical method}

All mathematical and graphing operations were performed using MATLAB-7.4.0 (R2007a) and Microsoft Office Excel-2003 programs. The ratio of the sum of the number of carbon atoms $\left(n_{c}\right)$ and the number of sulfur atoms $\left(n_{s}\right)$ to the product of these two numbers $\left(\mu_{c s}\right)$ is a useful numerical and structural value for the unsaturated thiocrown ethers 1-9 that were investigated $[75,76,86-90]$.

$\mu_{c s}=n_{s}+n_{c} /\left(n_{s} . n_{c}\right)$

If $n_{c}=2 n_{s}$, the coefficient of $\mu_{c s}$ is given by

$\mu_{c s}=3 /\left(2 n_{s}\right)$

For modeling, both linear (MLR: Multiple Linear Regressions) and nonlinear (ANN: Artificial Neural Network) models were examined. Other indices were examined and the best results and equations for extending the physicochemical and electrochemical data were chosen.

The Rehm-Weller equation estimates the free energy change between an electron donor $(D)$ and an acceptor $(A)$ as: [92]

$\Delta G_{e t}^{\circ}=\mathrm{e}\left[E_{D}^{\circ}-E_{A}^{\circ}\right]-\Delta E^{*}+\omega_{1}$

where " $e$ " is the unit electrical charge, $E_{\mathrm{D}^{\circ}}$ and $E_{\mathrm{A}}{ }^{0}$ are the reduction potentials of the electron donor and acceptor, respectively, $\Delta E^{*}$ is the energy of the singlet or triplet excited state, and $\omega_{1}$ is the work required to bring the donor and acceptor within the electron transfer (ET) distance. The work term in this expression can be considered to be ' 0 ' in so far as an electrostatic complex exists before the electron transfer [92].

The Marcus theory of electron transfer implies rather weak $(<0.05 \mathrm{eV})$ electronic coupling between the initial (locally excited, LE) and final (electron transfer, CT) states and presumes that the transition state is close to the crossing point of the LE and CT terms [93-100]. The value of the electron transfer rate constant $k_{e t}$ is controlled by the activation free energy $\Delta G^{\#} e$, which is a function of the reorganization energy $(l / 4)$ and the electron transfer driving force $\Delta G_{e t}[93-100]$.

$\Delta G^{\#} e t=(l / 4)\left(1+\Delta G_{e t} / l\right)^{2}$

$k_{e t}=k_{0} \exp \left(-\Delta G^{\#}{ }_{e t} / \mathrm{RT}\right)$

The reorganization energy of organic molecules ranges from 0.1-0.3 eV. In this study, was used the minimum amount of reorganization energy [93-100].

\section{Discussion}

The reduction potentials and redox behavior of 1-octynyl$\mathrm{C}_{60}$ anion (2-) were examined before by the use of cyclic voltammetry in THF and DMSO solvents [27]. Characteristic voltammogram results were observed by Komatsu et al. and their data were presented in Table 1, together with those reported for tert-Bu- $\mathrm{C}_{60}$ anion [27]. 
Table 2. Structural coefficients of unsaturated thiocrown ethers [X-UT-Y] 1-9 and the values of the free energy of electron transfer $\left(\Delta G_{e t(n),} \mathrm{n}=1-3\right)$, in $\mathrm{kcal}$ mol-1, between unsaturated thiocrown ethers, 1-9, with $\left[\mathrm{R}-\mathrm{C}_{60}{ }^{-} \mathrm{M}^{+}\right](\mathrm{R}=$ tert-Bu- \& Hex-C $\equiv \mathrm{C}-; \mathrm{M}=\mathrm{Li} \& \mathrm{~K}) \mathbf{1 0 - 1 1}$ in supramolecular $\left[[\mathrm{X}-\mathrm{UT}-\mathrm{Y}]\left[\mathrm{R}-\mathrm{C}_{60} 0^{-} \mathrm{M}^{+}\right](\mathrm{R}=\right.$ tert- $\mathrm{Bu}-\&$ Hex$\mathrm{C} \equiv \mathrm{C}-; \mathrm{M}=\mathrm{Li} \& \mathrm{~K}) \mathbf{1 2 - 3 8}$ complexes ${ }^{a}[27]$

\begin{tabular}{|c|c|c|c|c|c|c|c|c|c|}
\hline \multirow[t]{2}{*}{ No } & \multirow{2}{*}{$\begin{array}{l}\text { Formula of } \\
\text { [X-UT-Y] }\end{array}$} & \multirow[t]{2}{*}{$\mu_{c s}$} & \multirow{2}{*}{$\begin{array}{l}{ }^{o x} E_{1} \\
\text { (Volt) }\end{array}$} & \multicolumn{3}{|c|}{ [X-UT-Y][tert-Bu-C $\left.{ }_{60}{ }^{-} \mathrm{Li}^{+}\right]$12-20 solved in THF } & \multicolumn{3}{|c|}{ [X-UT-Y][tert-Bu-C $\left.{ }_{60}{ }^{-L^{+}}\right]$12-20 solved in DMSO } \\
\hline & & & & $\Delta G_{\text {et(1) }}$ & $\Delta G_{e t(2)}$ & $\Delta G_{e t(3)}$ & $\Delta G_{e t(1)}$ & $\Delta G_{e t(2)}$ & $\Delta G_{e t(3)}$ \\
\hline$\overline{1}$ & 6-UT-2(1,4-dithiin) & 0.7500 & 1.02 & $\begin{array}{l}58.05 \\
(58.11)\end{array}$ & $\begin{array}{l}69.82 \\
(69.87)\end{array}$ & $\begin{array}{l}82.96 \\
(83.02)\end{array}$ & $\begin{array}{l}52.06 \\
(52.12)\end{array}$ & $\begin{array}{l}63.59 \\
(63.65)\end{array}$ & - \\
\hline 2 & 9-UT-3 & 0.5000 & 0.97 & $\begin{array}{l}57.11 \\
(56.96)\end{array}$ & $\begin{array}{l}68.87 \\
(68.72)\end{array}$ & $\begin{array}{l}82.01 \\
(81.86)\end{array}$ & $\begin{array}{l}51.11 \\
(50.96)\end{array}$ & $\begin{array}{l}62.64 \\
(62.49)\end{array}$ & - \\
\hline 3 & 12-UT-4 & 0.3750 & 0.89 & $\begin{array}{l}55.20 \\
(55.11)\end{array}$ & $\begin{array}{l}66.96 \\
(66.87)\end{array}$ & $\begin{array}{l}80.10 \\
(80.02)\end{array}$ & $\begin{array}{l}49.20 \\
(49.12)\end{array}$ & $\begin{array}{l}60.73 \\
(60.65)\end{array}$ & - \\
\hline 4 & 15-UT-5 & 0.3000 & 0.82 & $\begin{array}{l}53.60 \\
(53.50)\end{array}$ & $\begin{array}{l}65.35 \\
(65.26)\end{array}$ & $\begin{array}{l}78.49 \\
(78.40)\end{array}$ & $\begin{array}{l}47.59 \\
(47.50)\end{array}$ & $\begin{array}{l}59.12 \\
(59.03)\end{array}$ & - \\
\hline 5 & 18-UT-6 & 0.2500 & 0.79 & $\begin{array}{l}52.33 \\
(52.81)\end{array}$ & $\begin{array}{l}64.08 \\
(64.57)\end{array}$ & $\begin{array}{l}77.29 \\
(77.71)\end{array}$ & $\begin{array}{l}46.33 \\
(46.81)\end{array}$ & $\begin{array}{l}57.86 \\
(58.34)\end{array}$ & - \\
\hline 6 & 21-UT-7 & 0.2143 & 0.73 & $\begin{array}{l}51.34 \\
(51.48)\end{array}$ & $\begin{array}{l}63.09 \\
(63.18)\end{array}$ & $\begin{array}{l}76.23 \\
(76.33)\end{array}$ & $\begin{array}{l}45.33 \\
(45.43)\end{array}$ & $\begin{array}{l}56.86 \\
(56.96)\end{array}$ & - \\
\hline 7 & 24-UT-8 & 0.1875 & 0.69 & $\begin{array}{l}50.54 \\
(50.50)\end{array}$ & $\begin{array}{l}62.29 \\
(62.26)\end{array}$ & $\begin{array}{l}75.43 \\
(75.41)\end{array}$ & $\begin{array}{l}44.53 \\
(44.51)\end{array}$ & $\begin{array}{l}56.06 \\
(56.04)\end{array}$ & - \\
\hline 8 & 27-UT-9 & 0.1667 & 0.66 & $\begin{array}{l}49.89 \\
(49.81)\end{array}$ & $\begin{array}{l}61.64 \\
(61.57)\end{array}$ & $\begin{array}{l}74.78 \\
(74.71)\end{array}$ & $\begin{array}{l}43.88 \\
(43.81)\end{array}$ & $\begin{array}{l}55.41 \\
(55.34)\end{array}$ & - \\
\hline 9 & 30-UT-10 & 0.1500 & 0.63 & $\begin{array}{l}49.35 \\
(49.12)\end{array}$ & $\begin{array}{l}61.10 \\
(60.88)\end{array}$ & $\begin{array}{l}74.24 \\
(74.02)\end{array}$ & $\begin{array}{l}43.33 \\
(43.12)\end{array}$ & $\begin{array}{l}54.87 \\
(54.65)\end{array}$ & - \\
\hline \multirow[t]{2}{*}{ No } & $\begin{array}{l}\text { Formula of } \\
{[X-U T-Y]}\end{array}$ & $\mu_{c s}$ & $\begin{array}{l}{ }^{o x} E_{1} \\
\text { (Volt) }\end{array}$ & \multicolumn{3}{|c|}{$[\mathrm{X}-\mathrm{UT}-\mathrm{Y}]\left[\mathrm{Hex}-\mathrm{C} \equiv \mathrm{C}-\mathrm{C}_{60}-\mathrm{Li}^{+}\right]$21-29 solved in DMSO } & \multicolumn{3}{|c|}{$[\mathrm{X}-\mathrm{UT}-\mathrm{Y}]\left[\mathrm{Hex}-\mathrm{C} \equiv \mathrm{C}-\mathrm{C}_{60}-\mathrm{K}^{+}\right]$30-38 solved in THF } \\
\hline & & & & $\Delta G_{e t(1)}$ & $\Delta G_{e t(2)}$ & $\Delta G_{e t(3)}$ & $\Delta G_{e t(1)}$ & $\Delta G_{e t(2)}$ & $\Delta \boldsymbol{G}_{e t(3)}$ \\
\hline 1 & 6-UT-2(1,4-dithiin) & 0.7500 & 1.02 & $\begin{array}{l}50.68 \\
(50.73)\end{array}$ & $\begin{array}{l}62.43 \\
(62.49)\end{array}$ & $\begin{array}{l}76.50 \\
(76.56)\end{array}$ & $\begin{array}{l}58.51 \\
(58.57)\end{array}$ & $\begin{array}{l}70.74 \\
(70.79)\end{array}$ & $\begin{array}{l}86.18 \\
(86.24)\end{array}$ \\
\hline 2 & 9-UT-3 & 0.5000 & 0.97 & $\begin{array}{l}49.73 \\
(49.58)\end{array}$ & $\begin{array}{l}61.49 \\
(61.34)\end{array}$ & $\begin{array}{l}75.56 \\
(75.41)\end{array}$ & $\begin{array}{l}57.57 \\
(57.42)\end{array}$ & $\begin{array}{l}69.79 \\
(69.64)\end{array}$ & $\begin{array}{l}85.24 \\
(85.09)\end{array}$ \\
\hline 3 & 12-UT-4 & 0.3750 & 0.89 & $\begin{array}{l}47.82 \\
(47.73)\end{array}$ & $\begin{array}{l}59.58 \\
(59.50)\end{array}$ & $\begin{array}{l}73.64 \\
(73.56)\end{array}$ & $\begin{array}{l}55.66 \\
(55.58)\end{array}$ & $\begin{array}{l}67.88 \\
(67.80)\end{array}$ & $\begin{array}{l}83.33 \\
(83.25)\end{array}$ \\
\hline 4 & 15-UT-5 & 0.3000 & 0.82 & $\begin{array}{l}46.20 \\
(46.12)\end{array}$ & $\begin{array}{l}57.97 \\
(57.88)\end{array}$ & $\begin{array}{l}72.03 \\
(71.95)\end{array}$ & $\begin{array}{l}54.05 \\
(53.96)\end{array}$ & $\begin{array}{l}66.27 \\
(66.18)\end{array}$ & $\begin{array}{l}81.72 \\
(81.63)\end{array}$ \\
\hline 5 & 18-UT-6 & 0.2500 & 0.79 & $\begin{array}{l}44.94 \\
(45.43)\end{array}$ & $\begin{array}{l}56.70 \\
(57.19)\end{array}$ & $\begin{array}{l}70.77 \\
(71.25)\end{array}$ & $\begin{array}{l}52.78 \\
(53.27)\end{array}$ & $\begin{array}{l}65.01 \\
(65.49)\end{array}$ & $\begin{array}{l}80.46 \\
(80.94)\end{array}$ \\
\hline 6 & 21-UT-7 & 0.2143 & 0.73 & $\begin{array}{l}43.95 \\
(44.05)\end{array}$ & $\begin{array}{l}55.71 \\
(55.80)\end{array}$ & $\begin{array}{l}69.78 \\
(69.87)\end{array}$ & $\begin{array}{l}51.79 \\
(51.88)\end{array}$ & $\begin{array}{l}64.01 \\
(64.11)\end{array}$ & $\begin{array}{l}79.46 \\
(79.56)\end{array}$ \\
\hline 7 & 24-UT-8 & 0.1875 & 0.69 & $\begin{array}{l}43.15 \\
(43.12)\end{array}$ & $\begin{array}{l}54.91 \\
(54.88)\end{array}$ & $\begin{array}{l}68.98 \\
(68.95)\end{array}$ & $\begin{array}{l}50.99 \\
(50.96)\end{array}$ & $\begin{array}{l}63.21 \\
(63.18)\end{array}$ & $\begin{array}{l}78.66 \\
(78.64)\end{array}$ \\
\hline 8 & 27-UT-9 & 0.1667 & 0.66 & $\begin{array}{l}42.50 \\
(42.43)\end{array}$ & $\begin{array}{l}54.26 \\
(54.19)\end{array}$ & $\begin{array}{l}68.33 \\
(68.26)\end{array}$ & $\begin{array}{l}50.34 \\
(50.27)\end{array}$ & $\begin{array}{l}62.56 \\
(62.49)\end{array}$ & $\begin{array}{l}78.09 \\
(77.94)\end{array}$ \\
\hline 9 & 30 -UT-10 & 0.1500 & 0.63 & $\begin{array}{l}41.96 \\
(41.74)\end{array}$ & $\begin{array}{l}53.71 \\
(53.50)\end{array}$ & $\begin{array}{l}67.78 \\
(67.57)\end{array}$ & $\begin{array}{l}49.79 \\
(49.58)\end{array}$ & $\begin{array}{l}62.02 \\
(61.80)\end{array}$ & $\begin{array}{l}77.47 \\
(77.25)\end{array}$ \\
\hline
\end{tabular}

$a$ The data for the compounds and their complexes have not been previously reported. The supramolecular $[\mathrm{X}-\mathrm{UT}-\mathrm{Y}]\left[\mathrm{R}-\mathrm{C}_{60}-\mathrm{M}+\right](\mathrm{R}=$ tert-Bu- $\&$ Hex-C $\equiv \mathrm{C}-; \mathrm{M}=\mathrm{Li} \&$ K) 12-38 complexes have not been synthesized nor reported previously.

They reported that the anion 2- in THF was oxidized to its radical at $-0.39 \mathrm{~V}$ vs ferrocene/ferrocenium $\left(\mathrm{Fc} / \mathrm{Fc}^{+}: 0.1 \mathrm{~V} / \mathrm{s}\right.$; supporting electrolyte, $\mathrm{Bu}_{4} \mathrm{NBF}_{4} ; 0.1 \mathrm{M}$ ), the corresponding reduction was shifted to $-1.20 \mathrm{~V}$, the difference of peak potentials being $0.81 \mathrm{~V}$ [27]. They investigated that this large negative shift of the cathodic peak was ascribed to some chemical process associated with the electron transfer, which is most probably a very rapid dimerization of the 1-octynyl- $\mathrm{C}_{60}$ radical [27]. The reduction of the dimer to the original monomeric anion 2- required extra energy for dissociation and also for structural change in $\mathrm{C}_{60}$ framework, which could have caused the cathodic shift as has been observed by Komatsu et al. [27]. The second and third reductions were nearly reversible as observed in individual redox waves [27]. In order to examine the structure and properties of anion 2-, semiempirical MO calculations (AM1) were conducted as has been done by Hirsch and co-workers for tert-Bu-C60 anion $[27,30](0.1 \mathrm{~V} / \mathrm{s}$; supporting electrolyte, $\mathrm{Bu}_{4} \mathrm{NBF}_{4} ; 0.1 \mathrm{M}$ ).

The reduction potentials of $\mathbf{1 - 9}$, shown in Table 2, demonstrate that the $\mu_{c s}$ index decreases with increasing the molecular size. In Table 2, related values for the supramolecular complexes of [X-UT-Y] 1-9 with $\mathrm{R}-\mathrm{C}_{60}-\mathrm{M}^{+}$; $\mathrm{R}=$ tert $-\mathrm{Bu}-\& \mathrm{H}-\mathrm{C} \equiv \mathrm{C}-(\mathrm{M}=\mathrm{Li}$ and $\mathrm{K})(\mathbf{1 0 - 1 2})$ were also shown. Table 2 shows the values of oxidation potential $\left({ }^{o x} E_{1}\right)$, as well as the calculated first and second free energies of electron

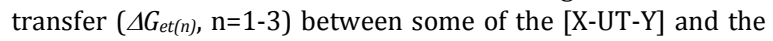
complexes 10-12 for supramolecular 13-15 complexes. The
${ }^{\operatorname{Red}} E_{n}(\mathrm{n}=1-3)$ data for $\mathbf{1 0}, \mathbf{1 1}$ and $\mathbf{1 2}$ are presented in Table 1 [16].

The oxidation potentials ( ${ }^{o x} E_{1}$ ) of 4-7 were found to be 0.82 , $0.79,0.73$ and $0.69 \mathrm{~V}$, respectively [34,35,86-90]. The free energies of electron transfer $\left(\Delta G_{e t(n),} n=1-3\right)$ between 1-9 and 10-12 for making [X-UT-Y] $\left[\mathrm{R}-\mathrm{C}_{60} 0^{-} \mathrm{M}^{+}\right](\mathrm{R}=$ tert-Bu- \& $\mathrm{H}-\mathrm{C} \equiv \mathrm{C}$-; $\mathrm{M}=\mathrm{Li} \& \mathrm{~K}$ ) (complexes 13-15) were calculated using the RehmWeller equation [86-90].

In Figure 1 supramolecular [X-UT-Y] $\left[\mathrm{R}-\mathrm{C}_{60}{ }^{-} \mathrm{M}^{+}\right](\mathrm{R}=$ tert-Bu\& Hex-C $\equiv C$-; $M=L i ~ \& ~ K)$ complexes were shown as groups 1238 in THF and DMSO solvents.

Table 3 shows the equations of the relationships between the $\mu_{c s}$ index and the first, second and third free energies of electron transfer $\left(\Delta G_{e t(n),} \mathrm{n}=1-3\right)$ between 1-9 with the molecules $\left[\mathrm{R}-\mathrm{C}_{60} 0^{-} \mathrm{M}^{+}\right](\mathrm{R}=$ tert-Bu- \& $\mathrm{H}-\mathrm{C} \equiv \mathrm{C}-; \mathrm{M}=\mathrm{Li} \& \mathrm{~K}) \mathbf{1 0}$ and 11 to produce [X-UT-Y] $\left[\mathrm{R}-\mathrm{C}_{60} \mathrm{M}^{+}\right](\mathrm{R}=$ tert- $\mathrm{Bu}-\&$ Hex-C$\equiv \mathrm{C}-$; $\mathrm{M}=\mathrm{Li} \& \mathrm{~K})$ in THF and DMSO solvents.

Figure 2 shows the plots of the relationship between $\mu_{c s}$ and the three free energies $\left(\Delta G_{e t(n)} \mathrm{n}=1-3\right.$ in $\left.\mathrm{kcal} \mathrm{mol}^{-1}\right)$ for electron transfer between 1-9 and [tert-But- $\left.\mathrm{C}_{60}-\mathrm{Li}^{+}\right]$to produce supramolecular [X-UT-Y] [tert-But- $60_{60} \mathrm{Li}^{+}$] (compounds 12-20) solved in THF. The related curves for other complexes [X-UT$\mathrm{Y}]\left[\mathrm{R}-\mathrm{C}_{60} 0^{-} \mathrm{M}^{+}\right](\mathrm{R}=$ tert $-\mathrm{Bu}-$ \& Hex-C $\equiv \mathrm{C}-; \mathrm{M}=\mathrm{Li} \& \mathrm{~K})$ 21-38 which they solved in THF and DMSO have similar structures to Figure 2 . The calculated values and the related equations of the three free energies of electron transfer $\left(\Delta G_{e t(n)} \mathrm{n}=1-3\right)$ were shown in Table 2 and 3 . 
Table 3. Second order polynomial equations (4-16) that indicate the relationship between the index $\mu_{c s}$ and the first and second free energies of electron transfer



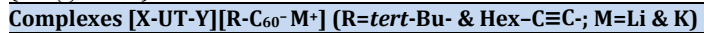
Number of complexes

\begin{tabular}{ll} 
Number of complexes & \\
\hline $12-20$ & THF \\
$12-20$ & THF \\
$12-20$ & THF \\
$12-20$ & DMSO \\
$12-20$ & DMSO \\
$21-29$ & DMSO \\
$21-29$ & DMSO \\
$21-29$ & DMSO \\
$30-38$ & THF \\
$30-38$ & THF \\
$30-38$ & THF \\
\hline
\end{tabular}

The values were obtained using the Rehm-Weller equation [92], for other complexes of 1-9 with [R- $\left.\mathrm{C}_{60}-\mathrm{M}^{+}\right](\mathrm{R}=$ tert-Bu- \& Hex-C $\equiv \mathrm{C}-; \mathrm{M}=\mathrm{Li} \& \mathrm{~K}) \mathbf{1 0 - 1 1}$ as $[\mathrm{X}-\mathrm{UT}-\mathrm{Y}]\left[\mathrm{R}-\mathrm{C}_{60} 0^{-} \mathrm{M}^{+}\right](\mathrm{R}=$ tert-Bu\& Hex-C $\equiv \mathrm{C}-; \mathrm{M}=\mathrm{Li} \& \mathrm{~K})$ 12-38.

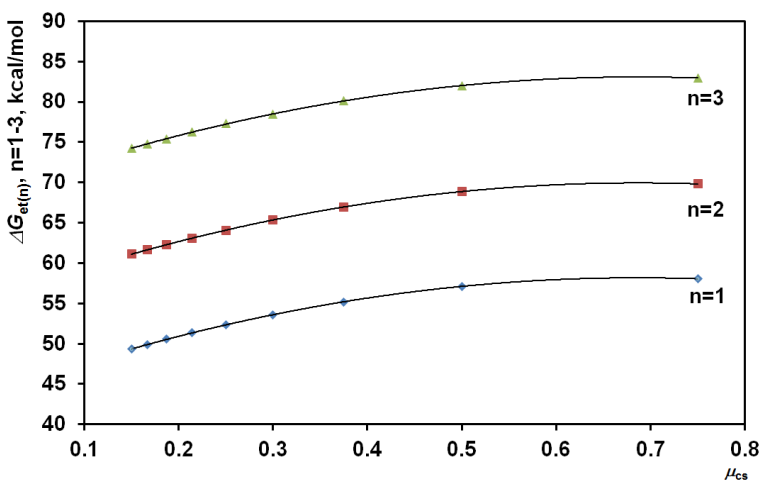

Figure 2. Plots of the relationship between the $\mu_{c s}$ index versus the first to third free energies of electron transfer $\left(\Delta G_{e t(n)} \mathrm{n}=1-3\right.$ in kcal mol-1) between 1-9 with [tert-But- $\mathrm{C}_{60}-\mathrm{Li}^{+}$] (compounds 12-20) to produce supramolecular [X-UT-Y] $\left[\right.$ tert-But- $\left.\mathrm{C}_{60}-\mathrm{Li}^{+}\right]$solved in THF. The related curves for other

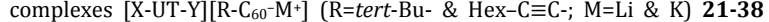
which they solved in THF and DMSO have similar structures to Figure 2.

Using equations 6-16 (Table 3), it is possible to obtain good approximations for the $\Delta G_{e t(n)}$ of supramolecular complexes 1220, 21-29 and 30-38 groups, in the first to third reduction potential states of [X-UT-Y] $\left[\mathrm{R}-\mathrm{C}_{60} 0^{-} \mathrm{M}^{+}\right](\mathrm{R}=$ tert-Bu- \& Hex-C $\equiv \mathrm{C}$-; $\mathrm{M}=\mathrm{Li} \& \mathrm{~K})$ 12-38 complexes, in THF and DMSO solvents. Equations 6-8 describe Figure 2. They show a quadratic relationship between $\Delta G_{e t(n)}(\mathrm{n}=1-3)$ and $\mu_{c s}$ for [X-UT-Y][tertBut- $\mathrm{C}_{60} \mathrm{Li}^{+}$] (compounds 12-20) solved in THF. In the complex groups, the $\mathrm{R}^{2}$ values for the graphs (Figure 2) are 0.995 and the appropriate equations are given in Table 3. In light of the good correlations between $\mu_{c s}$ and the free energies of electron transfer, it is possible to use $\mu_{c s}$ to calculate the $\Delta G_{e t(n)}$ of 12-38. The values of the $\Delta G_{e t}$ decrease with increasing group size (1-9) and decreasing $\mu_{c s}$ indices, as indicated in Table 2 and 3. Equations 9 and 10 return to the quadratic second order relationship between $\Delta G_{e t(n)}\left(\mathrm{n}=1\right.$ and 2) and $\mu_{c s}$ for [X-UTY] [tert-But- $\left.\mathrm{C}_{60}{ }^{-} \mathrm{Li}^{+}\right]$(compounds 12-20) solved in DMSO. In accordance with the data of Table 1, there was not any reported result for the third reduction potential $\left({ }^{\text {red }} E_{3}\right)$ of tert $-\mathrm{Bu}-\mathrm{C}_{60}-\mathrm{Li}^{+}$ in DMSO.

The values of the first to third free energies were shown in Table 2 for the electron transfer process between unsaturated thiocrown ethers 1-9 and the reduction potential of $\mathbf{1 0}$ and $\mathbf{1 1}$ as the complexes [X-UT-Y][Hex-C $\left.\equiv \mathrm{C}^{-} \mathrm{C}_{60}{ }^{-} \mathrm{Li}^{+}\right]$(in THF and DMSO solvents) (groups 21-29). The predicted values of $\Delta G_{\text {et }(n)}$ for the complexes 21-29 and other complexes were calculated using the Rehm-Weller equation. The equations of the relationship between values of $\mu_{c s}$ and the free energies of electron transfer $\Delta G_{e t(n)}$ of $\mathbf{2 1 - 2 9}$ were shown in Table 3. Equations 11 to 13 show quadratic polynomial structures. The $\mathrm{R}^{2}$ values that indicate correlation between $\mu_{c s}$ and the free energies of electron transfer of 21-29 (in red $E_{n}(\mathrm{n}=1-3)$ state of 11 in DMSO solvent) are all equal to 0.996. These good correlations between $\mu_{c s}$ and the free energies of electron transfer suggest that it is possible to use $\mu_{c s}$ to calculate the $\Delta G_{e t(n)}$ for [X-UT-Y][Hex-C $\left.\equiv \mathrm{C}-\mathrm{C}_{60} \mathrm{Li}^{+}\right]$(in DMSO solvents) (groups 21-29) by the equations of this model. This case is found to be similar to the other complexes, in which the values of the $\Delta G_{e t(n)}$ decrease with the increasing size (1-9) and decreasing $\mu_{c s}$ indices (see Table 2).

Equations 14-16 (Table 3) demonstrate the relationships between the free energies of electron transfer between 1-9 and 11 in [X-UT-Y] [Hex-C $\left.\equiv C-\mathrm{C}_{60}{ }^{-} \mathrm{K}^{+}\right]$(in THF solvent) (groups 3038) complexes with the $\mu_{c s}$ indices for the unsaturated thiocrown ethers, 1-9. These data were fitted using regression with a second-order polynomial. The amounts of $\mathrm{R}^{2}$ values for these graphs are 0.996. Using Equations 3 and 14-16, it is possible to calculate the values of $\Delta G_{e t(1)}$ to $\Delta G_{e t(3)}$ of [X-UT$\mathrm{Y}]\left[\mathrm{Hex}-\mathrm{C} \equiv \mathrm{C}-\mathrm{C}_{60}{ }^{-} \mathrm{K}^{+}\right]$complexes (groups $\mathbf{3 0 - 3 8}$ ) in THF solvent As shown in Table 2, similar to complexes 12-20 and 21-29 (in THF and DMSO solvents) the values of $\Delta G_{e t(n)}$ in the complexes decrease with increasing the size of 1-9 and decreasing $\mu_{c s}$ indices. In THF solvent the values of $\Delta G_{e t(1)}$ to $\Delta G_{\text {et(3) }}$ show greater amounts than DMSO in each group of 12-20, 21-29 and 30-38 complexes. It may returns back to the greater dipole moment and structural properties of DMSO than THF. It seems that these properties were susceptible the HOMO and LUMO level energies and the HOMO-LUMO energy gaps of the complexes in the groups 12-20, 21-29 and 30-38.

The ratio of sum of the number of carbon atoms $\left(n_{c}\right)$ and the number of sulfur atoms $\left(n_{s}\right)$ to the product of these two numbers, given by the index $\mu_{c s}$, shows a good relationship with structural values of the unsaturated thiocrown ethers, 1-9. These results show the calculated values of the free energies of electron transfer $\Delta G_{e t(1)}$ to $\Delta G_{e t(3)}$. On the basis of the first to third reduction potentials ( ${ }^{\mathrm{red}} E_{1}$ to ${ }^{\mathrm{red}} E_{3}$ states) the free energies of electron transfer were calculated for the supramolecular [XUT-Y] $\left[\mathrm{R}-\mathrm{C}_{60}{ }^{-} \mathrm{M}^{+}\right](\mathrm{R}=$ tert-Bu- \& Hex-C $\equiv \mathrm{C}-; \mathrm{M}=\mathrm{Li} \& \mathrm{~K})$ complexes as groups 12-38 in THF and DMSO solvents.

The Marcus theory is currently the dominant theory of electron transfer in chemistry. The Marcus theory is widely accepted because it accurately predicts electron transfer rates. The most significant prediction is that the rate of electron transfer will increase as the electron transfer reaction becomes more exergonic, but only to a point [94-100].

Electron transfer (ET) is one of the most important chemical processes in nature and plays a central role in many biological, physical and chemical (both organic and inorganic) systems. Solid-state electronics depends on controlling ET in semiconductors. Current molecular electronics depends critically on understanding and controlling the transfer of electrons in and between molecules and nanostructures. 
Table 4. Structural coefficients of unsaturated thiocrown ethers [X-UT-Y] 1-9 and the values of the free energy of electron transfer $\left(\Delta G^{\#}{ }_{e t}(n), \mathrm{n}=1-3\right)$, in kcal mol-1, between unsaturated thiocrown ethers, 1-9, with $\left[\mathrm{R}-\mathrm{C}_{60} \mathrm{M}^{\mathrm{M}}\right](\mathrm{R}=$ tert $-\mathrm{Bu}-\& \mathrm{HeX}-\mathrm{C} \equiv \mathrm{C}-; \mathrm{M}=\mathrm{Li} \& \mathrm{~K}) \mathbf{1 0}$ and 11$)$ in supramolecular $[\mathrm{X}-\mathrm{UT}-\mathrm{Y}]\left[\mathrm{R}-\mathrm{C}_{60}{ }^{-} \mathrm{M}^{+}\right](\mathrm{R}=$ tert-Bu- \& Hex-C $\equiv \mathrm{C}-; \mathrm{M}=\mathrm{Li} \& \mathrm{~K}) \mathbf{1 2 - 3 8}{ }^{a}[27]$.

\begin{tabular}{|c|c|c|c|c|c|c|c|}
\hline \multirow[t]{2}{*}{ No } & \multirow{2}{*}{$\begin{array}{l}\text { Formula of * } \\
\text { [X-UT-Y] }\end{array}$} & \multicolumn{3}{|c|}{ [X-UT-Y][tert-Bu-C $60^{-}$Li $\left.^{+}\right]$12-20 solved in THF } & \multicolumn{3}{|c|}{$[\mathrm{X}-\mathrm{UT}-\mathrm{Y}]\left[\right.$ tert-Bu-C$\left.{ }_{60}^{-} \mathrm{Li}^{+}\right] 12-20$ solved in $\mathrm{DMSO}^{b}$} \\
\hline & & $\Delta G^{\#} e t(1)$ & $\Delta G^{\#} e t(2)$ & $\Delta G^{\#} e t(3)$ & $\Delta G^{\#} e t(1)$ & $\Delta G^{\#} e t(2)$ & $\Delta G^{\#} e t(3)$ \\
\hline 1 & 6-UT-2(1,4-dithiin) & 122.88 & 169.55 & 230.62 & 101.99 & 143.94 & - \\
\hline 2 & 9-UT-3 & 118.72 & 164.66 & 224.86 & 98.17 & 139.39 & _ \\
\hline 3 & 12-UT-4 & 112.18 & 156.94 & 215.86 & 92.26 & 132.33 & _- \\
\hline 4 & $15-U T-5$ & 106.63 & 150.36 & 208.10 & 87.21 & 126.26 & - \\
\hline 5 & 18-UT-6 & 104.30 & 147.59 & 204.83 & 85.10 & 123.72 & - \\
\hline 6 & 21-UT-7 & 99.88 & 142.08 & 198.38 & 80.96 & 118.72 & - \\
\hline 7 & 24-UT-8 & 96.68 & 138.50 & 194.14 & 78.26 & 115.44 & - \\
\hline 8 & 27-UT-9 & 94.45 & 135.84 & 190.94 & 76.24 & 112.98 & - \\
\hline 9 & 30-UT-10 & 92.26 & 133.20 & 187.81 & 74.26 & 110.58 & - \\
\hline \multirow[t]{2}{*}{$\overline{\text { No }}$} & \multirow{2}{*}{$\begin{array}{l}\begin{array}{l}\text { Formula of } \\
\text { [X-UT-Y] }\end{array} \\
\end{array}$} & \multicolumn{3}{|c|}{$[\mathrm{X}-\mathrm{UT}-\mathrm{Y}]\left[\mathrm{Hex}-\mathrm{C} \equiv \mathrm{C}-\mathrm{C}_{60}-\mathrm{Li}^{+}\right]$21-29 solved in DMSO } & \multicolumn{3}{|c|}{ [X-UT-Y][Hex-C $\equiv \mathrm{C}^{\left.-\mathrm{C}_{60}-\mathrm{K}^{+}\right]} 30-38$ solved in THF } \\
\hline & & $\Delta G^{\#} e t(1)$ & $\Delta G^{\#} e t(2)$ & $\Delta G^{\#} e t(3)$ & $\Delta G^{\#} e t(1)$ & $\Delta G^{\#} e t(2)$ & $\Delta G^{\#} e t(3)$ \\
\hline$\overline{1}$ & 6-UT-2(1,4-dithiin) & 97.42 & 139.39 & 199.45 & 124.57 & 173.52 & 247.00 \\
\hline 2 & 9-UT-3 & 93.72 & 134.95 & 194.14 & 120.38 & 168.57 & 241.09 \\
\hline 3 & 12-UT-4 & 87.92 & 128.01 & 185.74 & 113.82 & 160.79 & 231.77 \\
\hline 4 & 15-UT-5 & 83.02 & 122.04 & 178.59 & 108.20 & 154.10 & 223.72 \\
\hline 5 & 18-UT-6 & 80.96 & 119.55 & 175.52 & 105.85 & 151.29 & 220.34 \\
\hline 6 & 21-UT-7 & 76.92 & 114.60 & 169.55 & 101.19 & 145.76 & 213.64 \\
\hline 7 & 24-UT-8 & 74.26 & 111.38 & 165.63 & 98.17 & 142.08 & 209.64 \\
\hline 8 & 27-UT-9 & 72.31 & 108.99 & 162.72 & 95.93 & 139.39 & 205.24 \\
\hline 9 & 30-UT-10 & 70.40 & 106.63 & 159.84 & 93.72 & 136.72 & 202.67 \\
\hline
\end{tabular}

complexes were neither synthesized nor reported previously.

${ }^{b}$ This derivative has not $k_{e t(3)}$ and $\Delta G^{\#} e_{t(3)}$ in DMSO.

Table 5. The values of the first to third free activation energies of electron transfer rate constants $\left(k_{e t}(n), \mathrm{n}=1-3\right)$ of $[\mathrm{X}-\mathrm{UT}-\mathrm{Y}]\left[\mathrm{R}-\mathrm{C}_{60}-\mathrm{M}{ }^{+}\right](\mathrm{R}=\operatorname{tert}-\mathrm{Bu}-\& \mathrm{Hex}-\mathrm{C} \equiv \mathrm{C}-$; $\mathrm{M}=\mathrm{Li}$ \& $\mathrm{K}) \mathbf{1 2 - 3 8}$ supramolecular complexes between 1-9 and 10 and 11.

\begin{tabular}{|c|c|c|c|c|c|c|c|}
\hline \multirow[t]{2}{*}{ No } & \multirow{2}{*}{$\begin{array}{l}\text { Formula of } \\
\text { [X-UT-Y] }\end{array}$} & \multicolumn{3}{|c|}{$\left[\mathrm{X}\right.$-UT-Y] $\left[\right.$ tert-Bu-C$\left.{ }_{60}^{-} \mathrm{Li}^{+}\right] 12-20$ solved in THF } & \multicolumn{3}{|c|}{$\left[\mathrm{X}\right.$-UT-Y][tert-Bu-C $\left.{ }_{60}-\mathrm{Li}^{+}\right]$12-20 solved in DMSO $a$} \\
\hline & & $k_{\text {et }(1)}$ & $\boldsymbol{k}_{\text {et (2) }}$ & $\boldsymbol{k}_{\text {et }(3)}$ & $k_{e t(1)}$ & $\boldsymbol{k}_{\text {et (2) }}$ & $\boldsymbol{k}_{e t(3)}$ \\
\hline $\mathbf{1}$ & 6-UT-2(1,4-dithiin) & $4.32 \times 10^{-78}$ & $2.54 \times 10^{-112}$ & $4.12 \times 10^{-157}$ & $9.07 \times 10^{-63}$ & $1.57 \times 10^{-93}$ & $-\cos (0)$ \\
\hline 2 & 9-UT-3 & $4.87 \times 10^{-75}$ & $9.87 \times 10^{-109}$ & $6.96 \times 10^{-153}$ & $5.76 \times 10^{-60}$ & $3.38 \times 10^{-90}$ & - \\
\hline 3 & $12-\mathrm{UT}-4$ & $3.07 \times 10^{-70}$ & $4.56 \times 10^{-103}$ & $2.75 \times 10^{-146}$ & $1.25 \times 10^{-55}$ & $5.10 \times 10^{-85}$ & - \\
\hline 4 & $15-U T-5$ & $3.58 \times 10^{-66}$ & $3.01 \times 10^{-98}$ & $1.36 \times 10^{-140}$ & $6.33 \times 10^{-52}$ & $1.43 \times 10^{-80}$ & - \\
\hline 5 & 18-UT-6 & $1.84 \times 10^{-64}$ & $3.25 \times 10^{-96}$ & $3.38 \times 10^{-138}$ & $2.23 \times 10^{-50}$ & $1.04 \times 10^{-78}$ & - \\
\hline 6 & 21-UT-7 & $3.24 \times 10^{-61}$ & $3.56 \times 10^{-92}$ & $1.82 \times 10^{-133}$ & $2.42 \times 10^{-47}$ & $4.88 \times 10^{-75}$ & - \\
\hline 7 & 24-UT-8 & $7.19 \times 10^{-59}$ & $1.52 \times 10^{-89}$ & $2.36 \times 10^{-130}$ & $2.32 \times 10^{-45}$ & $1.23 \times 10^{-72}$ & - \\
\hline 8 & 27-UT-9 & $3.06 \times 10^{-57}$ & $1.36 \times 10^{-87}$ & $5.23 \times 10^{-128}$ & $7.11 \times 10^{-44}$ & $7.91 \times 10^{-71}$ & - \\
\hline 9 & 30-UT-10 & $1.25 \times 10^{-55}$ & $1.17 \times 10^{-85}$ & $1.03 \times 10^{-125}$ & $1.98 \times 10^{-42}$ & $4.57 \times 10^{-69}$ & \\
\hline \multirow[t]{2}{*}{$\overline{\text { No }}$} & Formula of & \multicolumn{3}{|c|}{$[\mathrm{X}-\mathrm{UT}-\mathrm{Y}]\left[\mathrm{Hex}-\mathrm{C} \equiv \mathrm{C}-\mathrm{C}_{60}-\mathrm{Li}^{+}\right]$21-29 solved in DMSO } & \multicolumn{3}{|c|}{$[\mathrm{X}-\mathrm{UT}-\mathrm{Y}]\left[\mathrm{Hex}-\mathrm{C} \equiv \mathrm{C}-\mathrm{C}_{60}-\mathrm{K}^{+}\right] 30-38$ solved in THF } \\
\hline & [X-UT-Y] & $k_{e t(1)}$ & $\boldsymbol{k}_{\text {et (2) }}$ & $\boldsymbol{k}_{e t(3)}$ & $k_{e t(1)}$ & $\boldsymbol{k}_{\text {et (2) }}$ & $\boldsymbol{k}_{e t(3)}$ \\
\hline $\mathbf{1}$ & 6-UT-2(1,4-dithiin) & $2.04 \times 10^{-59}$ & $3.38 \times 10^{-90}$ & $3.00 \times 10^{-134}$ & $2.51 \times 10^{-79}$ & $3.12 \times 10^{-115}$ & $3.98 \times 10^{-169}$ \\
\hline 2 & 9-UT-3 & $1.06 \times 10^{-56}$ & $6.04 \times 10^{-87}$ & $2.36 \times 10^{-130}$ & $2.97 \times 10^{-76}$ & $1.34 \times 10^{-111}$ & $8.68 \times 10^{-165}$ \\
\hline 3 & 12-UT-4 & $1.91 \times 10^{-52}$ & $7.51 \times 10^{-82}$ & $3.39 \times 10^{-124}$ & $1.91 \times 10^{-71}$ & $6.73 \times 10^{-106}$ & $5.90 \times 10^{-158}$ \\
\hline 4 & 15-UT-5 & $7.51 \times 10^{-49}$ & $1.78 \times 10^{-77}$ & $5.99 \times 10^{-119}$ & $2.53 \times 10^{-67}$ & $5.46 \times 10^{-101}$ & $4.73 \times 10^{-152}$ \\
\hline 5 & 18-UT-6 & $2.42 \times 10^{-47}$ & $1.21 \times 10^{-75}$ & $1.06 \times 10^{-116}$ & $1.34 \times 10^{-65}$ & $6.25 \times 10^{-99}$ & $1.44 \times 10^{-149}$ \\
\hline 6 & 21-UT-7 & $2.21 \times 10^{-44}$ & $5.17 \times 10^{-72}$ & $2.54 \times 10^{-112}$ & $3.48 \times 10^{-62}$ & $7.20 \times 10^{-95}$ & $1.17 \times 10^{-144}$ \\
\hline 7 & 24-UT-8 & $1.98 \times 10^{-42}$ & $1.19 \times 10^{-69}$ & $1.91 \times 10^{-109}$ & $5.76 \times 10^{-60}$ & $3.56 \times 10^{-92}$ & $1.98 \times 10^{-141}$ \\
\hline 8 & 27-UT-9 & $5.30 \times 10^{-41}$ & $6.67 \times 10^{-68}$ & $2.60 \times 10^{-107}$ & $2.52 \times 10^{-58}$ & $3.33 \times 10^{-90}$ & $5.40 \times 10^{-139}$ \\
\hline 9 & 30-UT-10 & $1.35 \times 10^{-39}$ & $3.58 \times 10^{-66}$ & $3.40 \times 10^{-105}$ & $1.06 \times 10^{-56}$ & $3.06 \times 10^{-88}$ & $1.30 \times 10^{-136}$ \\
\hline
\end{tabular}

$a$ This derivative has not $k_{e t(3)}$ and $\Delta G^{\#}{ }_{e t(3)}$ in DMSO.

Electron transfer is a very simple chemical reaction, which can be used to gain insight into other kinds of chemistry and biochemistry. Electron transfer is fundamental in chemistry [93-100].

The free energy of electron transfer $\Delta G_{e t}$ is the difference between the reactants and the products, and $\Delta G_{e t} t^{\#}$ is the activation energy. The reorganization energy is the energy required to force the reactants to have the same nuclear configuration as the products without permitting the electron transfer. If the entropy changes are ignored, the free energy becomes energy or potential energy [93-100].

Using Equations 4 and 5, it is possible to calculate the activate free energies of electron transfer and kinetic rate constants of the electron transfers, $\Delta G^{\#} e t(n)$ and $k_{e t(n)}(\mathrm{n}=1-3)$, respectively, for 12-38 in accordance with Marcus theory. Figure 3 shows the surfaces of the free energies of electron transfer $\Delta G_{\text {ett }(n)}$ and $\Delta G_{e t(n)^{*}}(\mathrm{n}=1-3)$ between [X-UT-Y] 1-9 and $\left[\mathrm{R}-\mathrm{C}_{60}{ }^{-} \mathrm{M}^{+}\right] \quad(\mathrm{R}=$ tert $-\mathrm{Bu}-\quad \& \mathrm{Hex}-\mathrm{C} \equiv \mathrm{C}-; \mathrm{M}=\mathrm{Li} \& \mathrm{~K}) \mathbf{1 0 - 1 1}$ in supramolecular [X-UT-Y] $\left[\mathrm{R}-\mathrm{C}_{60}{ }^{-} \mathrm{M}^{+}\right](\mathrm{R}=$ tert-Bu- \& Hex-C $\equiv \mathrm{C}-$;

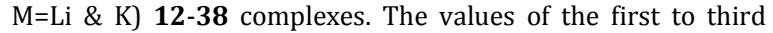
activation free energies of electron transfer, $\Delta G^{\#} e t(n)(n=1-3)$ for
12-20 and 21-29 in THF and DMSO solvents, decrease with $\Delta G_{e t(n)}$ and $\mu_{c s}$ descriptor, while the kinetic rate constants of the electron transfers $k_{e t(n)}(\mathrm{n}=1-3)$, increase with decreasing $\Delta G_{e t(n)}$ and $\Delta G_{e t(n)^{\#}}(\mathrm{n}=1-3)$ for 12-38. See Tables 4 and 5 and Figure 3. In THF solvent the values of $\Delta G_{\text {ett(1) }}$ t to $\Delta G_{\text {ett(3) }}$ \# show greater amounts than DMSO in each group of 12-20, 21-29 and 30-38 complexes. In notice to the reported results of the electron transfer rate constant $k_{e t(n)}(\mathrm{n}=1-3)$ in Table 5, the rate of electron transfer in DMSO is greater than THF.

Figure 3 shows the surfaces of the free energies of electron transfer $\Delta \operatorname{Get}_{(n)}$ and $\Delta \operatorname{Get}_{(n)}^{\#}$ (n=1 to 3 ) between 1-9 with 10 and $\mathbf{1 1}$ in the structures 12-38 complexes. The values were calculated by equations $1-16$, which they are shown in Tables $2-5$. With the appropriate equations and in light of the good correlations (see Figures 1-3 and equations 1-16), it is possible to calculate the values of the first to third free energies of electron transfer $\left(\Delta G_{e t}\right.$ in $\left.\mathrm{kcal} / \mathrm{mol}\right)$, the first to third activation free energies of electron transfer and kinetic rate constants of the electron transfers, $\Delta G^{\#} e t(n)$ and $k_{e t(n)}(\mathrm{n}=1-3)$, respectively, for 12-38 in THF and DMSO, in close accordance with the results of Marcus theory. 


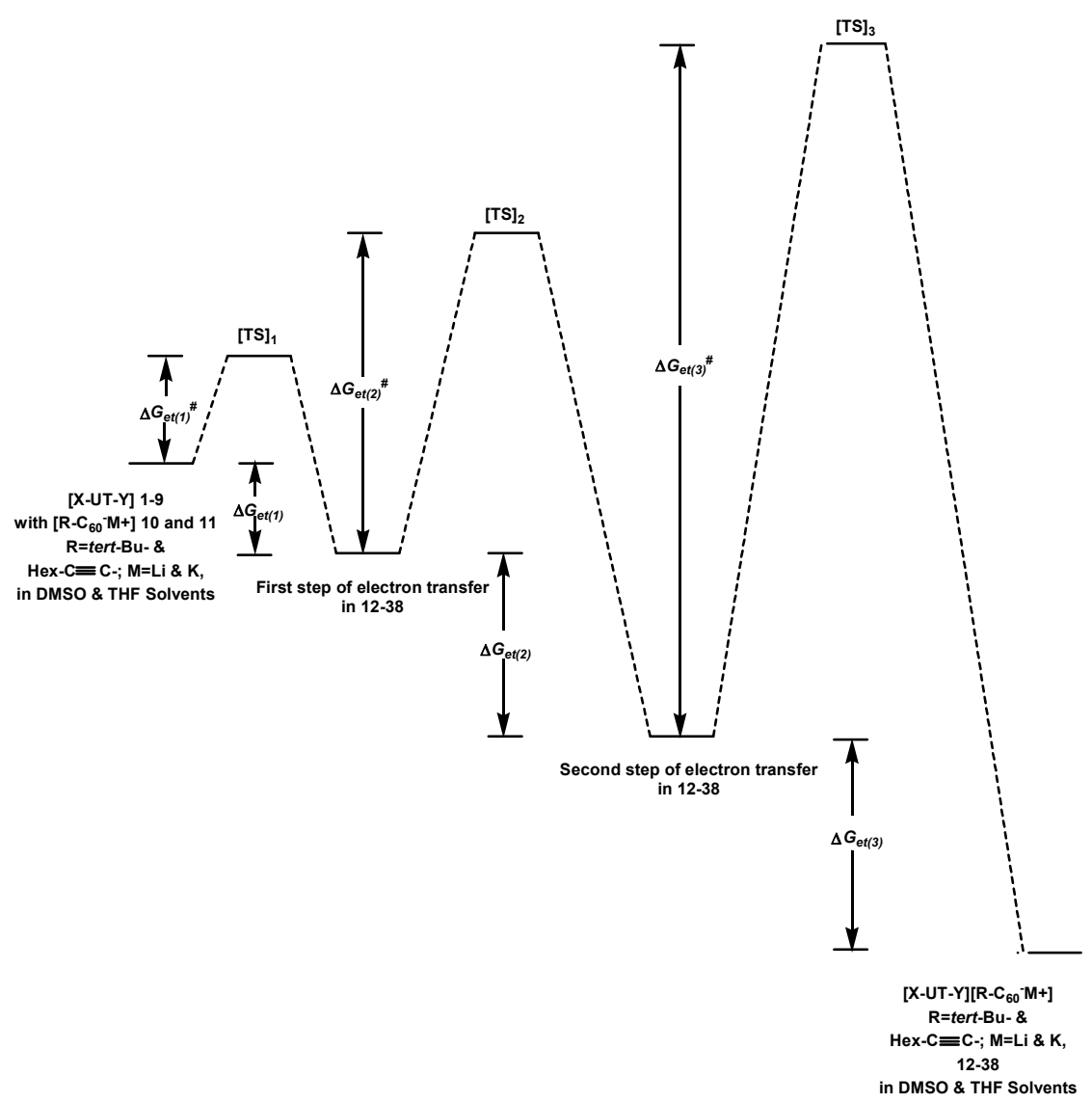

Figure 3. The surfaces of the free energies of electron transfer $\Delta G e t_{(n)}$ and $\Delta G e t_{(n)}(\mathrm{n}=1-3)$ between 1-9, 10 and 11 in 12-38.

The supramolecular complexes of unsaturated thiocrown ethers 1-9 with $\mathbf{1 0}$ and $\mathbf{1 1}$ as [X-UT-Y][Hex-C $\equiv \mathrm{C}-\mathrm{C}_{60}-\mathrm{Li}^{+}$] (in THF and DMSO solvents) (groups 21-29) and their electrochemical data $\Delta G_{e t(n), \Delta G^{\#} e t(n)}$ and $k_{e t(n)}(\mathrm{n}=1-3)$ have neither been synthesized nor reported before.

\section{Conclusion}

There have been three reduction potentials ( ${ }^{\text {red }} E_{1}$ to $\left.{ }^{r e d} E_{3}\right)$ states reported for $\left[\mathrm{R}-\mathrm{C}_{60}-\mathrm{M}^{+}\right](\mathrm{R}=$ tert-Bu- \& $\mathrm{Hex}-\mathrm{C} \equiv \mathrm{C}-; \mathrm{M}=\mathrm{Li}$ \& K) 10-11 in THF and DMSO solvents before. The cisunsaturated thiocrown ethers 1-9 have important physicochemical properties. Here, were reported the first to third free energies of electron transfer $\Delta G_{e t(n)}(n=1-3)$ on the basis of the electrochemical data of [X-UT-Y] 1-9 and the first to third reduction potential $\left({ }^{r e d} E_{1}\right.$ to $\left.{ }^{r e d} E_{3}\right)$ of the $\left[\mathrm{R}-\mathrm{C}_{60}-\mathrm{M}^{+}\right]$ ( $\mathrm{R}=$ tert-Bu- \& Hex-C $\equiv \mathrm{C}-; \mathrm{M}=\mathrm{Li} \& \mathrm{~K}$ ) 10-11, first and second activate free energies of electron transfer and kinetic rate constants of the electron transfers, $\Delta G^{\#} e t(n)$ and $k_{e t(n)}(\mathrm{n}=1-3)$, respectively, in the supramolecular complexes 12-38. The predicted values of $\Delta G_{\text {ett } n)}(\mathrm{n}=1-3)$ were calculated for 12-38 groups in THF and DMSO solvents using the Rehm-Weller equation. Using the ratio of sum of the number of carbon atoms $\left(n_{c}\right)$ and the number of sulfur atoms $\left(n_{s}\right)$ and the product of these two values, $\mu_{c s}$, equations were derived that yield good structural relationships with the aforementioned physicchemical data. These equations allow one to calculate $\Delta G_{\text {et }(n)}$ (n=1-3), $\Delta G^{\#} e t(n)$ and $k_{e t(n)}(\mathrm{n}=1-3)$ on the basis of the first and second reduction potential ( ${ }^{\mathrm{red}} E_{1}$ and $\left.{ }^{\mathrm{red}} E_{2}\right)$ of $\mathbf{1 0} \& \mathbf{1 1}$ for the 12-38 supramolecular complex groups. The values were calculated using the Rehm-Weller equation and equations 2-3 concern to the Marcus theory. The group of supramolecular complexes [X-UT-Y] $\left[\mathrm{R}-\mathrm{C}_{60}{ }^{-} \mathrm{M}^{+}\right](\mathrm{R}=$ tert-Bu- \& Hex-C $\equiv \mathrm{C}-; \mathrm{M}=\mathrm{Li}$ \& K) 12-38 were neither synthesized nor previously reported.

\section{Acknowledgments}

The corresponding author gratefully acknowledges the colleagues in the Chemistry Department of The University of Queensland (UQ)-Australia, for their useful suggestions.

\section{References}

[1]. Kroto, H. W.; Heath, J. R.; O'Brien, S. C.; Curl, R. F.; Smalley, R. E. Nature 1985, 318, 162-163.

[2]. Guhaa, S.; Nakamoto, K. Coord. Chem. Rev. 2005, 249, 1111-1132.

[3]. Murphy, T. A.; Pawlik, T. H; Weidinger, A.; Hohne, M.; Alcala, R.; Spath, J. M. Phys. Rev. Lett. 1996, 77, 1075-1078.

[4]. Billups, W. E. J. Am. Chem. Soc. 2005, 127(33), 11876.

[5]. Wang, L. S.; Conceicao, C.; Jin, C.; Smalley, R. E. Chem. Phys. Lett. 1991, 182, 5-11.

[6]. Boltalina, O. V.; Ioffe, I. N.; Sorokin I. D.; Sidorov, L. N. J. Phys. Chem 1997, 101(50), 9561-9563.

[7]. Heflin, J. R.; Marciu, D.; Figura C.; Wang, S.; Burbank, P.; Stevenson, S.; Dorn, H. C. Appl. Phys. Lett. 1998, 72, 2788.

[8]. Zettergren, H.; Alcami, M.; Martin, F. Chem. Phys. Chem. 2008, 9(6), 861-866.

[9]. Kato, H.; Taninaka, A.; Sugai, T.; Shinohara, H. J. Am. Chem. Soc. 2003, 125(26), 7782-7783.

[10]. Slanina, Z.; Chen, Z.; Schleyer, P. V. R.; Uhlik, F.; Lu, X.; Nagase, S. J. Phys. Chem. A. 2006, 110(6), 2231-2234.

[11]. Lu, X.; Nikawa, H.; Nakahodo, T.; Tsuchiya, T.; Ishitsuka, M. O.; Maeda, Y.; Akasaka, T.; Toki, M.; Sawa, H.; Slanina, Z.; Mizorogi, N.; Nagase, S. J. Am. Chem. Soc. 2008, 130(28), 9129-9136. 
[12]. Wakahara, T.; Nikawa, H.; Kikuchi, T.; Nakahodo, T.; Aminur Rahman, G. M.; Tsuchiya, T.; Maeda, Y.; Akasaka, T.; Yoza, K.; Horn, E.; Yamamoto, K.; Mizorogi, N.; Slanina Z.; Nagase, S. J. Am. Chem. Soc. 2006, 128(44), 14228-14229.

[13]. Kobayashi, K.; Nagase, S.; Yoshida M.; Osawa, E. J. Am. Chem. Soc. 1997, 119(51), 12693-12694.

[14]. Slanina, Z.; Kobayashi, K.; Nagase, S. Chem. Phys. Lett. 2003, 372(5-6), 810-814.

[15]. Slanina, Z.; Ishimura, K.; Kobayashi K.; Nagase, S. Chem. Phys. Lett. 2004, 384, 114-118.

[16]. Lu, X.; Nikawa H.; Nakahodo T.; Tsuchiya, T.; Ishitsuka, M. O; Maeda, Y.; Akasaka, T.; Toki, M.; Sawa, H.; Slanina, Z.; Mizorogi N.; Nagase, S. J. Am. Chem. Soc. 2008, 130(28), 9129-9136.

[17]. Wang, C.; Kai, T.; Tomiyama, T.; Yoshida, T.; Kobayashi, Y.; Nishibori, E.; Takata, M.; Sakata M.; Shinohara, H. Nature 2000, 408, 426.

[18]. Stevenson, S.; Fowler, P. W; Heine, T.; Duchamp, J. C.; Rice, G.; Glass, T.; Harich, K.; Hajdu, E.; Bible, R.; Dorn, H. C. Nature 2000, 408, 427-428.

[19]. Shi, Z.; Wu, X.; Wang, C.; Lu X.; Shinohara, H. Angew. Chem. Int. Ed. 2006, 45, 2107-2111.

[20]. Beavers, C. M.; Zuo, T.; Duchamp, J. C.; Harich, K.; Dorn, H. C.; Olmstead, M. M.; Balch, A. L. J. Am. Chem. Soc. 2006, 128(35), 1135211353.

[21]. Yang, S.; Popov, A. A.; Dunsch, L. Angew. Chem. Int. Ed. 2007, 46, 12561259.

[22]. Slanina, Z.; Chen, Z.; Schleyer, P. R.; Uhlik, F.; Lu, X.; Nagase, S. J. Phys. Chem. A. 2006, 110, 2231-2234.

[23]. Popov, A. A.; Dunsch, L. J. Am. Chem. Soc. 2007, 129(38), 11835-11849.

[24]. Park, S. S.; Liu, D.; Hagelberg, F. J. Phys. Chem. A. 2005, 109(39), 88658873.

[25]. Curry, J. D. J. Exp. Biol. 1999, 202, 3285-3294

[26]. Kamat, S.; Su, X.; Ballarini, R.; Heuer, A. H. Nature 2000, 405, 10361040.

[27]. Murata, Y.; Motoyama, K.; Komatsu, K.; Wan, T. S. M. Tetrahedron, 1996, 52(14), 5077-5090.

[28]. Bhyrappa, P. D. W.; Paul, P.; Stinchcombe, P.; Bolskar, J.; Sun, R. D.; Reed, C. A. J. Am. Chem. Soc. 1995, 117, 2907-2914.

[29]. Wudl, F.; Hirsh, A.; Khemani, K. C.; Suzuki, T.; Allemand, P. M.; Koch, A.; Eckert, H. , Srdanov, G.; Webb, H. M. In Fullerenes Synthesis, Properties, and Chemistry of Large Carbon Clusters; Hammond, G. S.; Kuck, V. J.; Eds.; ACS Symposium Series 48, American Chemical Society: Washington, DC, 1992, 161-175.

[30]. Hirsch, A.; Soi, A.; Karfunkel, H. R. Angew. Chem., Int. Ed. Engl. 1992, 31, 766-768.

[31]. Fagan, P. J.; Krusic, P. J.; Evans, D. H.; Lerke, S. A.; Johnston, E. J. Am. Chem. Soc. 1992, 114, 9697-9699.

[32]. Charton, M. In Progress in Physical Organic Chemistry, Ed.; rw Taft, Wiley: New York, 1981, Vol. 13, p. 119-251.

[33]. Anderson; H. L.; Faust, R.; Rubin, Y.; Diederich, F. Angew. Chem. 1994, 106, 1427-1429.

[34]. Tsuchiya, T.; Shimizu, T.; Kamigata, N. J. Am. Chem. Soc. 2001, 123(47), 11534-11538.

[35]. Tsuchiya, T.; Kurihara, H.; Sato, K.; Wakahara, T.; Akasaka, T.; Shimizu, T.; Kamigata, N.; Mizorogi N.; Nagase, S. Chem. Commun. 2006, 20, 3585-3587.

[36]. Anderson, M. R.; Dorn, H. C.; Stevenson, S. A. Carbon 2000, 38, 16631670.

[37]. Cooper, S. R. Acc. Chem. Res. 1988, 21(4), 141-146.

[38]. Blake, A. J.; Schroder, M.; Advances in Inorganic Chemistry, Ed. Sykes, A. G., Academic Press. Inc.: New York, 1990, Vol. 35, p 2 and references therein..

[39]. Rawle, S. C.; Cooper, S. R. J. Chem. Soc., Chem. Commun. 1987, 4, 308309.

[40]. Parker, D. Macrocycle Synthesis: A Practical Approach, Ed. , Oxford University Press: New York, 1996.

[41]. Pedersen, C. J. J. Org. Chem. 1971, 36(2), 254-257.

[42]. Murray, S. G.; Hartley, F. R. Chem. Rev. 1981, 81(4), 365-414.

[43]. Nakayama, J.; Kaneko, A.; Sugihara, Y.; Ishii, A. Tetrahedron. 1999, 55(33), 10057-10066.

[44]. Weaver, J. H.; Chai, Y.; Kroll, G. H.; Jin, C.; Ohno, T. R.; Haufler, R. E.; Guo, T.; Alford, J. M.; Conceicao, J.; Chibante, L. P. F.; Jain, A.; Palmer, G.; Smalley, R. E. Chem. Phys. Lett. 1992, 190(5), 460-464.

[45]. Smalley, R. E.; Hamond, G. S.; Kuck, V. J.; Editor, Fullerenes, Washington DC: American Chemical Society, pp. 1992, 141-59.

[46]. Yannoni, C. S.; Hoinkis, M.; De Vries, M. S.; Bethune, D. S.; Salem, J. R.; Crowder, M. S.; Johnson R. D.; Robert, D. Science 1992, 256, 11911192.

[47]. Ruoff, R. S.; Kadish, K. M.; Boulas, P.; Chen, E. C. M. J. Phys. Chem. 1995, 99(21), 8843-8850.

[48]. Fowler, P. W. Manolopoulos, D. E.; In: An Atlas of Fullerenes, Vol. 30, Oxford: Clarendon Press, 1995.

[49]. Hoffman, K. R.; Delapp, K.; Andrews, H.; Sprinkle, P.; Nickels, M.; Norris, B. J. Lumin. 1995, 66-67(1-6), 244-248.

[50]. Dennis, T. J. S.; Kai, T.; Tomiyama, T.; Shinohara, H. Chem. Commun. 1998, 5, 619-620.
[51]. Stevenson, S.; Dorn, H. C.; Burbank, P. M.; Harich, K.; Haynes, J. Kiang, C. H.; Salem, J. R.; de Vries, M. S.; Van Loosdrecht, P. H. M.; Johnson, R. D.; Yannoni, C. S.; Bethune, D. S. Anal. Chem. 1994, 66(17), 2675-2679.

[52]. Iiduka, Y.; Wakahara, T.; Nakajima, K.; Tsuchiya, T.; Nakahodo, T. Maeda, Y.; Akasaka, T.; Mizorogi N.; Nagase, S. Chem. Commun. 2006, 19, 2057-2059.

[53]. Slanina, Z.; Kobayashi, K.; Nagase, S. J. Chem. Phys. 2004, 120, 33973400 .

[54]. Nagase, S.; Kobayashi, K. Chem. Phys. Lett. 1994, 231(2-3), 319-324.

[55]. Hansen, P. J.; Jurs, P. J. Chem. Edu. 1988, 65, 574-580.

[56]. Hosoya, H. Bull. Chem. Soc. Jpn. 1971, 44, 2332-2339.

[57]. Randic, M. Acta Chim. Slov. 1998, 4, 239-252.

[58]. Rucker G.; Rucker, C. J. Chem. Inf. Comput. Sci. 1999, 39, 788-802.

[59]. Wiener, H. J. Am. Chem. Soc. 1947, 69, 17-20.

[60]. Du, Y. P.; Liang, Y. Z.; Li B. Y.; Xu, C. J. J. Chem. Inf. Comput. Sci. 2002, 42, 1128-1138.

[61]. Randic, M. J. Am. Chem. Soc. 1975, 97, 6609-6615

[62]. Sabljic A.; Trinajstic, N. Acta Pharm. Ugosl. 1981, 31, 189-214.

[63]. Sybold, P. G.; May, M.; Bagal, U. A. J. Chem. Edu. 1987, 64(7), 575-582.

[64]. Kier L. B.; Hall, L. H.; Molecular Connectivity in Chemistry and Drug Research, Academic Press, New York, 1976.

[65]. Randic, M. J. Math. Chem. 1991, 7, 155-168.

[66]. Randic, M.; and Mills, D.; Basak, S. C. Int. J. Quantum Chem. 2000, 80, 1199-1209.

[67]. Randic, M.; Plavsic; D.; Lers, N. J. Chem. Inf. Comput. Sci. 2001, 41, 657662

[68]. Randic, M.; Basak, S. C. J. Chem. Inf. Comput. Sci. 2001, 41, 614-618.

[69]. Randic. M.; Pompe, M. J. Chem. Inf. Comput. Sci. 2001, 41, 575-581.

[70]. Kier, L. B.; Hall, L. H. Molecular Connectivity in Structure-Activity, Research Studies Press, John Wiley and Sons: Letchworth, England, 1986.

[71]. Gutman, I.; Randic, M. Chem. Phys. Lett. 1977, 47, 15-19.

[72]. Wiener, H. J. Am. Chem. Soc. 1947, 69(1), 17-20.

[73]. Kier, L. B. Quant. Struc. Act. Relat. 1985, 4, 109-116.

[74]. Kier L. B.; Hall, L. H. Molecular Structure Description: The Electrotopological State, Academic Press, New York, 1999.

[75]. Balaban, A. Chem. Phys. Lett. 1982, 89(5), 399-404.

[76]. Hu, Q. N.; Liang, Y. Z. Internet Electron. J. Mol. Des. 2004, 3(6), 335-349.

[77]. Barysz, M.; Plavsic, D.; Trinajstic, N. Match. 1986, 19, 89-116.

[78]. Estrada, E. Chem. Phys. Lett. 2008, 463(4-6), 422-425.

[79]. Taherpour A. A.; Shafiee, F. J. Mol. Struct., Theochem. 2005, 726, 183188.

[80]. Hansch, C.; Leo, A.; Hoekman, D. Exploring QSAR: Hydrophobic, Electronic, Steric Constants, ACS, Washington, DC, USA, 1995.

[81]. Bundy, J. G.; Morriss, A. W. J.; Durham, D. G.; Campbell C. D.; Paton, G. I. Chemosphere. 2001, 42, 885-892.

[82]. Li, A.; Yalkowsky, S. H. Ind. Eng. Chem. Res. 1998, 37, 4470-4475.

[83]. Bolboaca, S. D.; Jantschi, L. Int. J. Mol. Sci. 2007, 8, 335-345.

[84]. Slanina, Z.; Chao, M. C.; Lee, S. L.; Gutman, I. J. Serb. Chem. Soc. 1997, 62(3), 211-217.

[85]. Plavsic, D.; Nikolic, S.; Trinajstic, N.; Mihalic, Z. J. Math. Chem. 1993, 12 , 235-250.

[86]. Taherpour, A. A. Full., Carb. Nanot., Carb. Nanostruct. 2007, 15, 405415.

[87]. Taherpour, A. A. Full., Carb. Nanot., Carb. Nanostruct. 2008, 16(2), 142-153.

[88]. Taherpour, A. A. Full., Carb. Nanot., Carb. Nanostruct. 2009, 17(2), 171- 186.

[89]. Taherpour, A. A.; Asadi, T. Full., Carb. Nanot., Carb. Nanostruct. 2011 19, 166-181.

[90]. Taherpour, A. A. Phosph. Sulf. Silic. 2010, 185, 422-432.

[91]. Murata, Y.; Motoyama, K.; Komatsu, K.; Wan, T. S. M. Tetrahedron 1996, 52, 5077-5090

[92]. Rehm, A.; Weller, A. Isr. J. Chem. 1970, 8, 259-271.

[93]. Marcus, R. A. Modern Phys. 1993, 65(3), 599-610.

[94]. Andrea, M. Marcus Theory for Electron Transfer a short introduction MPIP-Journal Club-Mainz-January 29, 2008.

[95]. Barbara P. F. J. Phys. Chem. 1996, 100, 13148-13161.

[96]. Newton, M. D. Chem. Rev. 1991, 91, 767-792.

[97]. Jortner, J.; Freed, K. F. J. Chem. Phys. 1970, 52, 6272-6291.

[98]. Marcus, R. A. J. Chem. Phys. 1965, 43, 679-701.

[99]. Marcus, R. A.; Sutin, N. Biochim. Biophys. Acta. 1985, 811, 265-322.

[100]. Kuzmin, M. G. XVIIth IUPAC Symposium on Photochemistry, Dresden, German, July 22-27, 2000, Book of Abstracts, p. 372. 